\title{
Categorizing Asthma Severity: An Overview of National Guidelines
}

\author{
Gene L. Colice, MD, Pulmonary, Critical Care and Respiratory Services, Washington Hospital Center, and \\ The George Washington University School of Medicine, Washington, District of Columbia
}

\author{
REPRINT REQUESTS: \\ Gene Colice, MD \\ Washington Hospital Center \\ 110 Irving Street, NW \\ Washington, DC 20010 \\ Telephone: 202-877-7856 \\ Fax: 202-291-0386 \\ Email: Gene.Colice@Medstar.net
}

\section{KEYWORDS:}

Asthma; Severity of illness index; Therapeutics; Bronchodilator agents; Administration, inhalation

\section{DISCLOSURE:}

Dr. Colice has acted as a consultant for GlaxoSmithKline, Aventis, Novartis, Sepracor, Altana, Kos, Om, Schering Plough, Pfizer, Boehringer Ingelheim, and $3 \mathrm{M}$ pharmaceutical companies.

\section{RECEIVED:}

MARCH 24, 2004

REVISED AND ACCEPTED:

JUNE 16, 2004

Clinical Medicine \& Research

Volume 2, Number 3: 155-163

(02004 Clinical Medicine \& Research

http://www.mfldclin.edu/clinmedres

\begin{abstract}
Asthma is an inflammatory disease of the airways associated with intermittent episodes of bronchospasm. Corticosteroids are the most effective anti-inflammatory class of medication currently available for the treatment of asthma. However, as higher doses of inhaled corticosteroids are used the risks of systemic exposure and side effects will correspondingly increase. Justification of the benefits from higher doses of inhaled corticosteroids can only be made if patients with more severe asthma can be identified. Methods to categorize asthma severity have been introduced in various national asthma management guidelines. Unfortunately, there are substantial conceptual and practical differences among these recommended approaches to asthma severity categorization. Furthermore, these recommended approaches suffer from a focus on features of asthma control, such as symptoms, short-acting beta-agonist use, and lung function rather than actual measures of asthma severity that would encompass markers of airway inflammation. Without the endpoints necessary to assess airway inflammation, current recommendations for asthma severity categorization may lead to systematic under dosing of appropriate anti-inflammatory therapy with subsequent perpetuation of the asthma exacerbation cycle.
\end{abstract}

\section{INTRODUCTION}

Asthma is an inflammatory disease of the airways associated with intermittent episodes of bronchospasm. ${ }^{1}$ Bronchodilators can effectively relieve bronchospasm, but do not treat the underlying airway inflammation. Currently, corticosteroids are the most effective anti-inflammatory class of medication available for the treatment of asthma. When given in the inhaled form, especially at low doses, corticosteroids act as topical anti-inflammatory agents in the airways with little risk of systemic exposure. ${ }^{2}$ Inhaled corticosteroids have been shown to effectively reduce airway inflammation, 3,4 control asthma symptoms, improve lung function, decrease exacerbations, ${ }^{5}$ and reduce hospitalization ${ }^{6}$ and mortality rates ${ }^{7,8}$ from asthma. However, as higher doses of inhaled corticosteroids are used the risks of systemic exposure ${ }^{2}$ and side effects will correspondingly increase ${ }^{9}$.

The benefits of higher doses of inhaled corticosteroids may be less substantial than previously thought. A recent meta-analysis indicated that maximal symptom 
and lung function improvements were found at low-to-medium doses (table 1) of inhaled fluticasone propionate. ${ }^{10}$ Similar observations were made in a 24-week study comparing increasing doses of inhaled fluticasone propionate and beclomethasone dipropionate. ${ }^{11}$ A study employing bronchial biopsies also failed to confirm enhanced in vivo anti-inflammatory benefits with very high doses of fluticasone propionate. ${ }^{12}$ Doubling the dose of an inhaled corticosteroid during asthma deterioration, a common clinical approach, provides little benefit in preventing an exacerbation. ${ }^{13}$. It is only in highly select groups of patients with such severe asthma requiring chronic oral corticosteroids that very high doses of inhaled corticosteroids seem to provide additional benefits to improving lung function, symptom control, quality of life and the ability to reduce oral corticosteroids. ${ }^{14,15}$

Similarly, the clinically relevant risks of systemic adverse effects from the long-term use of inhaled corticosteroids are less than generally perceived. Inhaled corticosteroids are known to suppress the hypothalamic-pituitary-adrenal axis, but are very rarely the cause of clinically recognizable adrenal insufficiency. ${ }^{16}$ Parents are concerned that inhaled corticosteroids might affect the growth of their children. Growth velocity does transiently decrease with initiation of inhaled corticosteroid treatment in prepubertal children, but this effect does not seem to result in diminution of actual height attained. ${ }^{17,18}$ The risk of developing either cataracts $^{19,20}$ or osteoporosis ${ }^{21}$ is small. Skin bruising does occur with long-term use of inhaled corticosteroids, especially in the elderly, but this is primarily a cosmetic problem. ${ }^{22,23}$ Although these observations are reassuring, it must be acknowledged that long-term use of high doses of inhaled corticosteroids have been associated with such side effects as Cushing's syndrome, growth retardation, osteopenia, myopathy and cataracts. ${ }^{19,20,24}$

The benefit versus risk profile of inhaled corticosteroids is clearly favorable at low-to-medium doses. Considerable benefit can be achieved with little risk of adverse systemic effects. Use of higher doses of inhaled corticosteroids should be restricted to those carefully defined clinical circumstances in which the anticipated benefits can be justified against the risk of systemic side effects. Justification of the benefits from higher doses of inhaled corticosteroids can only be made if patients with more severe asthma can be identified.

\section{METHODS OF CATEGORIZING ASTHMA SEVERITY}

There are three basic methods advocated by various national guidelines to categorize asthma severity. The first method, developed by a consensus panel convened through the US National Asthma Education and Prevention Program and presented as the Expert Panel Report 2, relies on an assessment of asthma symptoms and lung function at the time the patient is being evaluated prior to the initiation of treatment. ${ }^{25}$ Three variables are considered in categorizing asthma severity: daytime symptoms, nighttime symptoms and lung function (table 2). Abnormalities within each of these three variables are graded into four separate categories of severity. Overall asthma severity is categorized according to the worst individual variable. For example, if a patient has frequent nighttime symptoms (placing them in the severe, persistent category for this variable) but has daytime symptoms less than twice per week and normal lung function (both in the mild, intermittent category), the overall asthma categorization is severe, persistent.

The National Asthma Campaign in Australia ${ }^{26}$ advocates the second method. A description of the development of this method is not given, but presumably it was based on consensus of experts. This method stipulates that asthma severity should be assessed while the patient is clinically stable, but also adds that a history of either hospitalization or near-fatal asthma attacks should be taken into consideration in severity categorization (table 3). Like the method established in the Expert Panel Report 2, the worst individual categorization will determine overall asthma severity. An additional consideration to asthma severity categorization is the identification of the "high risk" patient. There is overlap between variables used to categorize asthma severity and characteristics of the "high risk" patient. However, other factors, such as poor compliance with treatment, denial of asthma as a personal medical problem, history of asthma initiated by aspirin or other nonsteroidal

Table 1. Comparative Daily Doses of Inhaled Corticosteroids ${ }^{25}$

\begin{tabular}{|c|c|c|c|}
\hline Drug & Low Dose ${ }^{\dagger}$ & Medium Dose $^{\dagger}$ & High Dose ${ }^{\dagger}$ \\
\hline Beclomethasone dipropionate & 168 to 504 & 504 to 840 & $>840$ \\
\hline Budesonide Turbuhaler & 200 to 400 & 400 to 600 & $>600$ \\
\hline Flunisolide & 500 to 1000 & 1000 to 2000 & $>2000$ \\
\hline Fluticasone propionate & 88 to 264 & 264 to 660 & $>660$ \\
\hline Triamcinolone acetonide & 400 to 1000 & 1000 to 2000 & $>2000$ \\
\hline
\end{tabular}

\footnotetext{
$\uparrow$ dosages listed in micrograms.
} 
anti-inflammatory drugs, and immediate hypersensitivity to foods are included as high-risk characteristics. Identifying a high risk patient will not necessarily lead to changes in therapy, but does indicate the need for closer follow-up.

The British Guideline on the Management of Asthma 27 provides a third method for categorizing asthma severity. It emphasizes control of symptoms and maintenance of normal lung function, but specifies that symptom control should be based on individual assessment and that normal lung function and complete relief of symptoms may not always be possible. This approach differs from both the US and Australian methods as specific categories of asthma severity are not described, but rather steps are defined based on the need for medications to achieve individual asthma control. The British guidelines were developed through an evidence-based process, but no specific evidence is provided to support the recommended approach to determining asthma severity. Similarly to the US approach, the British guidelines identify daytime symptoms, need for short-acting beta-agonists, exacerbations, physical activity limitations and lung function as the important endpoints of asthma management.

The Canadian guidelines for asthma care, developed through consensus of experts, include two separate methods for determining asthma severity. ${ }^{28}$ The first recommended approach is similar in concept to the method advocated in the British guidelines. Physicians define acceptable asthma control based on daytime symptoms, nighttime symptoms, physical activity limits, exacerbations, absence from school or work, use of rescue short-acting beta-agonists, and lung function. Asthma severity is categorized through assessment of symptom control and need for medication (table 4). The second Canadian approach is similar to the Australian method. It combines features of lung function, symptom

Table 2. Classification of Asthma Severity: Method of Expert Panel Report $2^{25}$

\begin{tabular}{llll}
\hline Severity & Symptoms & $\begin{array}{l}\text { Nighttime } \\
\text { Symptoms }\end{array}$ & Lung Function \\
\hline Severe persistent & $\begin{array}{l}\text { Continual symptoms } \\
\text { Limited physical activity } \\
\text { Frequent exacerbations }\end{array}$ & Frequent & FEV $1 /$ PEF $\leq 60 \%$ \\
& PEF variability $>30 \%$
\end{tabular}

FEV 1 : forced expiratory volume in one second; PEF: peak expiratory flow

Table 3. Classification of Asthma Severity: Method of Australian National Asthma Campaign 26

\begin{tabular}{|c|c|c|c|c|c|c|c|c|}
\hline Severity & $\begin{array}{l}\text { Wheeze, } \\
\text { tightness, } \\
\text { cough, } \\
\text { dyspnea }\end{array}$ & $\begin{array}{l}\text { Nighttime } \\
\text { symptoms }\end{array}$ & $\begin{array}{l}\text { Symptoms } \\
\text { on waking }\end{array}$ & $\begin{array}{l}\text { Admission or } \\
\text { emergency } \\
\text { visits }\end{array}$ & $\begin{array}{l}\text { Previous life } \\
\text { threatening } \\
\text { attack }\end{array}$ & $\begin{array}{l}\text { Short-acting } \\
\text { beta-agonist } \\
\text { use }\end{array}$ & $\mathrm{FEV}_{1}$ & PEF \\
\hline Severe & Every day & $>1 /$ week & $>1 /$ week & Usually & $\begin{array}{l}\text { May have a } \\
\text { history }\end{array}$ & $>3$ to $4 /$ day & $<60 \%$ & $<80 \%$ \\
\hline Moderate & Most days & $<1 /$ week & $<1 /$ week & Usually not & Usually not & Most days & $60 \%$ to $80 \%$ & $80 \%$ to $90 \%$ \\
\hline Mild & Occasional & Absent & Absent & Absent & Absent & $<2 /$ week & $>80 \%$ & $>90 \%$ \\
\hline
\end{tabular}

FEV1: forced expiratory volume in one second; PEF: peak expiratory flow 
control, history of hospital admissions, and near-fatal asthma attacks to determine asthma severity (table 5).

There are conceptual differences among these approaches to severity categorization. The US approach, detailed in the Expert Panel Report 2, concentrates on current symptoms and lung function abnormalities, while the Australian method incorporates historical features. The Expert Panel Report 2 advises medication dosing according to pretreatment severity; the British guideline uses the reverse approach, inferring severity categorization from the amount of medication required to control symptoms and maximize lung function. There are also specific procedural differences among the guidelines. The Expert Panel Report 2 has four different severity categories and makes a fundamental distinction between persistent and intermittent asthma. The Australian approach uses only three severity categories: mild, moderate, and severe. In the British guideline, separate asthma severity categories are not specified, but five different steps of asthma treatment approaches are described. The Canadians use five separate severity categories, ranging from very mild to very severe, in one approach, that reflects the British method, and three separate categories in their other approach, similar to the Australian method. Each of the guidelines recommends using an assessment of daily symptoms, exacerbations, nighttime symptoms, and use of short-acting beta-agonists as an important basis for determining asthma severity. Although the recommended approaches use similar symptoms, they differ in how individual severity categories are distinguished based on these symptoms. For instance, in the Expert Panel Report 2 nighttime symptoms occurring more than once per week would be graded as moderate, persistent, while in the Australian approach nighttime symptoms occurring with that frequency would be considered indicative of severe asthma. In one Canadian method the use of short-acting beta-agonists 3-6 times per day would indicate moderate severity; in the Australian recommendations use of short-acting beta-agonists with such a frequency would indicate severe asthma. Interestingly, there is good agreement among the guidelines on how severity categories are distinguished based upon objective criteria of lung function.

\section{ASTHMA SEVERITY CATEGORIZATION METHODS IN CURRENT GUIDELINES - A CRITICAL ASSESSMENT}

Concern has been expressed about the methods used to develop recommendations for severity categorization in these national guidelines. ${ }^{29}$ One area of weakness is in the use of consensus to develop recommendations. Only the British method specifically states that it was evidence based, but no evidence was cited to support the general approach of implicitly defining asthma severity through the type of medications needed to achieve asthma control. Guidelines, especially those developed by specialty societies, have been criticized for not adhering to established methodologic standards for evaluating and synthesizing the scientific evidence. ${ }^{30,31}$ The original Expert Panel Report on diagnosis and management of asthma has been faulted for relying on the subjective judgment of the panel through consensus rather than supporting recommendations with clear scientific evidence. ${ }^{32}$ Unfortunately, the Expert Panel Report 2 used the same methods.

Implementation of these recommendations is another area of concern. If recommendations about severity categorization are to be used by health care providers, careful field-testing prior to dissemination for implementation is advisable to ensure that the guidelines can be properly understood. At the University of Iowa, researchers asked asthma specialists and

Table 4. Classification of Asthma Severity: Method of Canadian Consensus 28

\begin{tabular}{lll}
\hline Severity & Symptoms & Treatment \\
\hline Very severe & $\begin{array}{l}\text { May be controlled or } \\
\text { not well controlled }\end{array}$ & $\begin{array}{l}\text { Short-acting beta-agonist use } \\
\text { High doses of inhaled corticosteroids } \\
\text { Additional therapy } \\
\text { Oral corticosteroids }\end{array}$ \\
Severe & Well controlled & Short-acting beta-agonist use \\
& & High doses of inhaled corticosteroids \\
Moderate & Well controlled & Additional therapy \\
& & Short-acting beta-agonist use \\
& & Low-to-moderate doses of inhaled corticosteroids \\
& & Additional therapy \\
Mild & Well controlled & Short-acting beta-agonist use occasionally \\
& & Low doses of inhaled corticosteroids
\end{tabular}


Table 5. Classification of Asthma Severity: Method of Canadian Consensus 28

\begin{tabular}{llllll}
\hline Severity & FEV $/$ PEF & $\begin{array}{l}\text { Short-acting } \\
\text { beta-agonist } \\
\text { use }\end{array}$ & $\begin{array}{l}\text { Near-fatal } \\
\text { episode }\end{array}$ & $\begin{array}{l}\text { Hospital } \\
\text { admission }\end{array}$ & $\begin{array}{l}\text { Nighttime } \\
\text { symptoms }\end{array}$ \\
\hline Severe & $<60 \%$ & Q 2 to $4 \mathrm{hr}$ & + & + & $\begin{array}{l}\text { Limitation } \\
\text { of daily } \\
\text { activities }\end{array}$ \\
Moderate & $60 \%$ to $80 \%$ & $\mathrm{Q} 4$ to $8 \mathrm{hr}$ & - & - & +++ \\
Mild & $>80 \%$ & $<8 \mathrm{~h}$ & - & - & $-/+$ \\
\hline
\end{tabular}

Symptom: not reported, - ; reported, + ; reported more often, ++ and +++ $\mathrm{FEV}_{1}$ : forced expiratory volume in one second; PEF: peak expiratory flow

family medicine faculty to answer questions about the Expert Panel Report 2 method of asthma severity categorization. ${ }^{33}$ Family medicine faculty answered $56 \%$ of the questions correctly; asthma specialists scored only $7 \%$ better, answering only $63 \%$ of the questions correctly. Recently, Baker and colleagues ${ }^{34}$ found that pediatric allergists and pulmonologists demonstrated poor agreement in assessing asthma severity in a series of case vignettes, despite being provided the Expert Panel Report 2 methods. These observations suggest that considerable education will be required for health care providers to understand and effectively use recommended methods for asthma severity categorization in national guidelines.

Issue has been taken with the principle that grading of the worst individual category should determine overall asthma severity categorization. Two studies involving large numbers of patients evaluated how the Expert Panel Report 2 methods actually categorize asthma and found that the majority of patients were categorized as moderate-to-severe. 35,36 This observation is contradictory to the prevailing belief that most patients actually have mild asthma. ${ }^{37}$ Surprisingly, in one large study a single variable, nighttime symptoms, seemed to be the most important determinant of overall asthma severity categorization. ${ }^{36}$ These observations raise two important issues: if one variable is playing a predominant role in determining severity categorization, it limits the value of an approach that emphasizes considering multiple factors, and an asthma severity categorization method that places most patients in only one or two categories may not have adequate discriminatory resolution.

The guidelines emphasize reliance on asthma symptoms and lung function for determining asthma severity. There are important methodologic issues involved in developing an asthma severity categorization method that incorporates symptoms and objective measures of lung function on the same scale. For example, the Expert Panel Report 2 includes the separate variables daytime symptoms and lung function on a scale ranging from mild, intermittent to severe, persistent asthma. Consequently, continual symptoms have the same significance as a $\mathrm{FEV}_{1}$ (forced expiratory volume in one second) below $60 \%$ predicted. This intuitively makes sense to the clinician, but is difficult to support scientifically because numerous studies have shown that there is poor correlation between reporting of asthma symptoms and objective measures of lung function. $36,38,39$ Other observations make it difficult to support scaling symptoms and lung function in the same way. Patients cannot reliably predict changes in their lung function based on the symptoms they experience ${ }^{40}$ and physicians cannot accurately predict lung function from examinations of patients with asthma. ${ }^{41}$

Changes in symptoms are a poor indicator of impending changes in lung function. ${ }^{42}$ Symptom reporting may be affected by factors other than asthma itself. Women may report more symptoms and rely more heavily on use of short-acting beta-agonists than men with the same degree of airway obstruction. ${ }^{43}$ Negative mood may be an important determinant of short-acting beta-agonist use and perception of asthma symptoms. ${ }^{44}$ Most worrisome has been the repeated observation that both patients and physicians may substantially underestimate the severity of asthma, especially when they make this estimate based primarily on symptoms. ${ }^{45,46}$ Although the guidelines appropriately incorporate measures of lung function, as well as symptom assessment, they fail to take into account the unfortunate reality that most primary care providers do not routinely incorporate objective measures of lung function into their assessment of asthma. ${ }^{47}$ Consequently, on a practical basis implementation of guideline recommended asthma severity categorization will not be possible until health care providers accept the value of spirometry and incorporate its use into their everyday practice.

A more fundamental and conceptual concern about the recommended approaches to asthma severity categorization is that these methods are based on the concept of asthma control rather than asthma severity. ${ }^{48}$ Symptoms and lung function indicate how well the manifestations of the disease are controlled, but do not reflect the severity of the underlying inflammation. As asthma is accepted to be an inflammatory airway disease, severity categorization would be most reasonably based on an assessment of airway inflammation. Current guidelines provide insight into airway inflammation only indirectly, by integrating the dose of inhaled corticosteroids needed to provide control of symptoms. However, direct methods are available to assess airway inflammation. Induced sputum allows measurement 
of airway inflammatory cells; changes in sputum eosinophil counts may reflect deterioration in asthma control. 49 Bronchoscopy is increasingly used for bronchoalveolar lavage to measure airway inflammatory cell counts and airway biopsy is used to directly evaluate airway remodeling and inflammation. ${ }^{50}$ Exhaled levels of nitric oxide ${ }^{51}$ and tests of bronchial hyperresponsiveness ${ }^{52}$ may indirectly reflect airway inflammation.

The importance of airway inflammation as the measure of asthma severity is demonstrated by recent observations in patients at the extreme ends of the asthma spectrum, those with mild, intermittent asthma and those with very severe asthma. Mild, intermittent asthma, as defined in the Expert Panel Report 2, describes patients using short-acting beta-agonists infrequently for symptom control. Because these patients are categorized as having intermittent asthma and do not use inhaled corticosteroids, it is implied that on-going airway inflammation is not present. However, elevated exhaled nitric oxide levels and bronchial biopsy evidence of airway inflammation have been found in patients with mild, intermittent asthma. ${ }^{53,54}$ In a small group of young adults with a history of asthma but no clinical evidence of asthma for over one year, bronchial biopsy specimens have confirmed on-going evidence of airway inflammation. ${ }^{55}$ Low dose exposure to allergens in a group of patients with mild asthma under controlled research conditions has been shown to worsen airway inflammation without significantly changing asthma symptoms. ${ }^{56}$ These observations indicate that perhaps absent or minimal symptoms may not truly reflect disease activity. It has been noted that near-fatal and fatal episodes of asthma occur in patients with seemingly mild disease, 57 it is possible that in these patients an assessment of airway inflammation, rather than symptoms and lung function, would have indicated more severe disease. Bronchial biopsy studies have indicated that there may be two different types of inflammatory processes in adults with very severe asthma, a neutrophilic dominant and an eosinophilic dominant form. ${ }^{58}$ This observation has been confirmed in studies using induced sputum. ${ }^{59}$ In children with very severe asthma, bronchoscopic biopsy has actually shown extensive remodeling with little inflammation. ${ }^{60}$ Clinically, patients with very severe asthma have fluctuations in symptoms and lung function despite aggressive treatment with inhaled and oral corticosteroids. The studies of airway inflammation suggest that their disease may not be corticosteroid responsive. Using dosage of inhaled corticosteroids as a surrogate marker of disease severity would not be appropriate in these patients.

Two studies have directly evaluated the added value of incorporating measures of airway inflammation into an approach for asthma management. Sont and colleagues 61 randomized asthma patients to a treatment strategy based on either asthma severity categorized by the Expert Panel Report 2 alone or asthma severity categorization along with methacholine inhalation challenge studies as a measure of bronchial hyperreactivity. Bronchial hyperreactivity was used in this study as an index of underlying airway inflammation. The patients treated according to measures of bronchial hyperreactivity received higher doses of inhaled corticosteroids, but had significantly fewer episodes of asthma exacerbation and significantly more effective control of airway inflammation as determined by bronchial biopsies. Green et al. ${ }^{62}$ randomized patients with asthma either to a management approach based on the British guidelines of symptom and lung function control or to another path incorporating use of induced sputum eosinophil counts. The group treated according to measures of airway inflammation had significantly fewer asthma exacerbations. These studies suggest that asthma would more effectively be controlled if severity were categorized using an index of airway inflammation, rather than solely through control of symptoms and lung function.

\section{CONCLUSIONS}

Asthma is a frustrating disease for both patients and health care providers. It is a common disease; approximately $7 \%$ of the US population currently suffers from asthma. ${ }^{63}$ Patients with asthma often feel that their disease is not treated effectively. Surveys reveal that most asthma patients limit their activities because of respiratory symptoms and as a consequence, report dissatisfaction with their lifestyles. ${ }^{64}$ Health care providers recognize that routine asthma care requires millions of office visits annually and that acute asthma problems prompt many additional emergency department visits. ${ }^{63}$ Asthma still causes deaths, especially in high risk inner city populations. ${ }^{63}$ Persistent asthma can cause deterioration in lung function over time, e.g., conversion from reversible airflow obstruction to irreversible airflow obstruction as seen in chronic obstructive pulmonary disease. ${ }^{65,66}$

Frustration with asthma care is especially apparent now because patients and health care providers have multiple effective options for treatment. Despite remarkable advances in asthma pharmacotherapy, patients with asthma often adhere poorly to the recommended treatment regimens. ${ }^{67}$ Poor adherence relates, in part, to difficulties asthma patients have in understanding that asthma is an inflammatory disease that requires long-term anti-inflammatory preventive measures. Poor adherence also is based on concerns about potential side effects of asthma medications. For example, patients report that they frequently do not use inhaled short-acting beta-agonists because of associated side effects. ${ }^{68}$ Concerns by patients about the side effect profile of inhaled corticosteroids are even greater. Compounding the effects of patients' poor adherence to asthma treatment regimens has been the historic reluctance of American physicians to regularly prescribe inhaled corticosteroids for asthma. ${ }^{69,70}$ Recent trends suggest that treatment regimens for asthma are beginning to increase the inclusion of inhaled corticosteroids, but there is still a too frequent tendency to inappropriately rely on beta-agonists alone for asthma therapy. ${ }^{71}$ For both patients and health care providers, 
education about appropriate pharmacotherapy is the key to better asthma care. The foundation of education regarding asthma pharmacotherapy is in understanding the balance between the benefits of inhaled corticosteroids and the potential risks.

There is clear rationale for categorizing asthma severity. Higher doses of inhaled corticosteroids can only be justified if patients with more severe asthma can be identified. National asthma management guidelines have attempted to address this issue by proposing asthma severity categorization methods. Unfortunately, despite extensive efforts to disseminate these guidelines, surveys and database evaluations consistently show that current asthma care around the world fails to adhere to the recommendations of these guidelines. ${ }^{72-74}$ These observations are disturbing because underassessment of asthma severity results in ineffective treatment and suboptimal outcomes. ${ }^{75,76}$ Even though the recommended approaches for asthma severity categorization suffer from various methodologic flaws, management of asthma patients according to these guidelines would still result in improved care. ${ }^{77-80} \mathrm{~A}$ more difficult issue concerns the inherent limitations of the current asthma severity categorization methods, especially the failure to include measures of airway inflammation. Without the endpoints necessary to assess airway inflammation, current recommendations for asthma severity categorization may lead to systematic under dosing of appropriate anti-inflammatory therapy with subsequent perpetuation of the asthma exacerbation cycle. Incorporation of measures such as methacholine challenge testing and sputum eosinophil counts into routine asthma care may improve the ability to assess the severity of underlying airway inflammation and to more appropriately adjust anti-inflammatory therapy.

\section{REFERENCES}

1. Busse WW, Lemanske RF Jr. Asthma. N Engl J Med 2001;344:350-362.

2. Lawrence M, Wolfe J, Webb DR, Chervinsky P, Kellerman D, Schaumberg JP, Shah T. Efficacy of inhaled fluticasone propionate in asthma results from topical and not systemic activity. Am J Respir Crit Care Med 1997;156:744-751

3. Laitinen LA, Laitinen A, Haahtela T. A comparative study of the effects of an inhaled corticosteroid, budesonide, and a beta 2-agonist, terbutaline, on airway inflammation in newly diagnosed asthma: a randomized, double-blind, parallel-group controlled trial. J Allergy Clin Immunol 1992;90:32-42.

4. Trigg CJ, Manolitsas ND, Wang J, Calderon MA, McAulay A, Jordan SE, Herdman MJ, Jhalli N, Duddle JM, Hamilton SA, Devalia JL, Davies RJ. Placebo-controlled immunopathologic study of four months of inhaled corticosteroids in asthma. Am J Respir Crit Care Med 1994;150:17-22.

5. Pauwels RA, Pedersen S, Busse WW, Tan WC, Chen YZ, Ohlsson SV, Ullman A, Lamm CJ, O'Byrne PM; START Investigators Group. Early intervention with budesonide in mild persistent asthma: a randomized, double-blind trial. Lancet 2003;361:1071-1076.

6. Donahue JG, Weiss ST, Livingston JM, Goetsch MA, Greineder DK, Platt R. Inhaled steroids and the risk of hospitalization for asthma. JAMA 1997;277:887-891.
7. Suissa S, Ernst P, Benayoun S, Baltzan M, Cai B. Low-dose inhaled corticosteroids and the prevention of death from asthma. N Engl J Med 2000;343:332-336.

8. Lanes SF, Garcia Rodriguez LA, Huerta C. Respiratory medications and risk of asthma death. Thorax 2002;57:683-686.

9. Lipworth BJ. Systemic adverse effects of inhaled corticosteroid therapy: a systematic review and meta-analysis. Arch Intern Med 1999;159:941-955.

10. Holt S, Suder A, Weatherall M, Cheng S, Shirtcliffe P, Beasley $R$. Dose-response relation of inhaled fluticasone propionate in adolescents and adults with asthma: meta-analysis. BMJ 2001;323:253-256.

11. Szefler SJ, Martin RJ, King TS, Boushey HA, Cherniack RM, Chinchilli VM, Craig TJ, Dolovich M, Drazen JM, Fagan JK, Fay JV, Fish JE, Ford JF, Israel E, Kiley J, Kraft M, Lazarus SC, Lemanske RF Jr, Mauger E, Peters SP, Sorkness CA; Asthma Clinical Research Network of the National Heart, Lung and Blood Institute. Significant variability in response to inhaled corticosteroids for persistent asthma. J Allergy Clin Immunol 2002;109:410-418.

12. O'Sullivan S, Cormican L, Murphy M, Poulter LW, Burke CM. Effects of varying doses of fluticasone propionate on the physiology and bronchial wall immunopathology in mild-to-moderate asthma. Chest 2002;122:1966-1972.

13. Harrison TW, Oborne J, Newton S, Tattersfield AE. Doubling the dose of inhaled corticosteroid to prevent asthma exacerbations: randomized controlled trial. Lancet 2004;363:271-275

14. Noonan M, Chervinsky P, Busse WW, Weisberg SC, Pinnas J, de Boisblanc BP, Boltansky H, Pearlman D, Repsher L, Kellerman D. Fluticasone propionate reduces oral prednisone use while it improves asthma control and quality of life. Am J Respir Crit Care Med 1995;152(5 Pt 1):1467-1473.

15. Fish JE, Karpel JP, Craig TJ, Bensch GW, Noonan M, Webb DR, Silverman B, Schenkel EJ, Rooklin AR, Ramsdell JW, Nathan R, Leflein JG, Grossman J, Graft DF, Gower RG, Garay SM, Frigas E, Degraff AC, Bronsky EA, Bernstein DI, Berger W, Shneyer L, Nolop KB, Harrison JE. Inhaled mometasone furoate reduces oral prednisone requirements while improving respiratory function and health-related quality of life in patients with severe persistent asthma. J Allergy Clin Immunol 2000;106:852-860.

16. Todd GR, Acerini CL, Ross-Russell R, Zahra S, Warner JT, McCance D. Survey of adrenal crisis associated with inhaled corticosteroids in the United Kingdom. Arch Dis Child 2002;87:457-461.

17. Long-term effects of budesonide or nedocromil in children with asthma. The Childhood Asthma Management Program Research Group. N Engl J Med 2000;343:1054-1063.

18. Agertoft L, Pedersen S. Effect of long-term treatment with inhaled budesonide on adult height in children with asthma. N Engl J Med 2000;343:1064-1069.

19. Garbe E, Suissa S, LeLorier J. Association of inhaled corticosteroid use with cataract extraction in elderly patients. JAMA 1998;280:539-543.

20. Smeeth L, Boulis M, Hubbard R, Fletcher AE. A population based case-control study of cataract and inhaled corticosteroids. Br J Ophthalmol 2003;87:1247-1251.

21. Gluck O, Colice GL. Recognizing and treating glucocorticoid-induced osteoporosis in patients with pulmonary diseases. Chest 2004;125:1859-1876.

22. Mak VH, Melchor R, Spiro SG. Easy bruising as a side-effect of inhaled corticosteroids. Eur Respir J 1992;5:1068-1074.

23. Lung Health Study Research Group. Effect of inhaled triamcinolone on the decline in pulmonary function in chronic obstructive pulmonary disease. N Engl J Med 2000;343:1902-1909. 
24. Covar RA, Leung DY, McCormick D, Steelman J, Zeitler P, Spahn JD. Risk factors associated with glucocorticoid-induced adverse effects in children with severe asthma. J Allergy Clin Immunol 2000;106:651-659.

25. National Asthma Education and Prevention Program, Expert Panel Report 2. Guidelines for the Diagnosis and Management of Asthma. Washington, DC: Dept of Health and Human Services; 1997. NIH Publication No. 97-4051.

26. Asthma Management Handbook 1998, National Asthma Campaign. South Melbourne, Australia: National Asthma Council Austrailia Ltd, ACN 058044 634; 1998.

27. British Guideline on the Management of Asthma. Thorax 2003;58(S1):i1-i94.

28. Boulet LP, Becker A, Berube D, Beveridge R, Ernst P. Canadian asthma consensus report, 1999. Canadian Asthma Consensus Group. CMAJ 1999;161(11 Suppl):S1-S61.

29. Colice GL. The seduction of asthma severity categorization. Chest 2003;124:2054-2056.

30. Shaneyfelt TM, Mayo-Smith MF, Rothwangl J. Are guidelines following guidelines? The methodological quality of clinical practice guidelines in peer-reviewed medical literature. JAMA 1999;281:1900-1905.

31. Grilli R, Magrini N, Penna A, Mura G, Liberati A. Practice guidelines developed by specialty societies: the need for a critical appraisal. Lancet 2000;355:103-106.

32. Berg AO, Moy JG. Guidelines for the diagnosis and management of asthma. J Am Board Fam Pract 1992;5:629634.

33. Doerschug KC, Peterson MW, Dayton CS, Kline JN. Asthma guidelines: an assessment of physician understanding and practice. Am J Respir Crit Care Med 1999;159:1735-1741.

34. Baker KM, Brand DA, Hen J Jr. Classifying asthma: disagreement among specialists. Chest 2003;124:2156-2163.

35. Fuhlbrigge AL, Adams RJ, Guilbert TW, Grant E, Lozano P, Janson SL, Martinez F, Weiss KB, Weiss ST. The burden of asthma in the United States: level and distribution are dependent on interpretation of the national asthma education and prevention program guidelines. Am J Respir Crit Care Med 2002;166:1044-1049.

36. Colice GL, Burgt JV, Song J, Stampone P, Thompson PJ. Categorizing asthma severity. Am J Respir Crit Care Med 1999;160:1962-1967.

37. Auerbach I, Springer C, Godfrey S. Total population survey of the frequency and severity of asthma in 17 year old boys in an urban area of Israel. Thorax 1993;48:139-141.

38. Teeter JG, Bleecker ER. Relationship between airway obstruction and respiratory symptoms in adult asthmatics. Chest 1998;113:272-277.

39. Shingo S, Zhang J, Reiss TF. Correlation of airway obstruction and patient-reported endpoints in clinical studies. Eur Respir J 2001;17:220-224.

40. Kendrick AH, Higgs CM, Whitfield MJ, Laszlo G. Accuracy of perception of severity of asthma: patients treated in general practice. BMJ 1993;307:422-424.

41. Shim CS, Williams MH Jr. Evaluation of the severity of asthma: patients versus physicians. Am J Med 1980;68:11-13.

42. Leone FT, Mauger EA, Peters SP, Chinchilli VM, Fish JE, Boushey HA, Cherniack RM, Drazen JM, Fahy JV, Ford J, Israel E, Lazarus SC. Lemanske RF, Martin RJ, McGeady SJ, Sorkness C, Szefler SJ; Asthma Clinical Research Network of the National Heart, Lung, and Blood Institute. The utility of peak flow, symptom scores, and beta-agonist use as outcome measures in asthma clinical research. Chest 2001;119:1027-1033.

43. Osborne ML, Vollmer WM, Linton KL, Buist AS. Characteristics of patients with asthma within a large HMO: a comparison by age and gender. Am J Respir Crit Care Med 1998; 157:123-128.
44. Main J, Moss-Morris R, Booth R, Kaptein AA, Kolbe J. The use of reliever medication in asthma: the role of negative mood and symptom reports. J Asthma 2003;40:357-365.

45. Nguyen BP, Wilson SR, German DF. Patients' perceptions compared with objective ratings of asthma severity. Ann Allergy Asthma Immunol 1996;77:209-215.

46. Boulet LP, Phillips R, O'Byrne P, Becker A. Evaluation of asthma control by physicians and patients: comparison with current guidelines. Can Respir J 2002;9:417-423.

47. O'Dowd LC, Fife D, Tenhave T, Panettieri RA Jr. Attitudes of physicians toward objective measures of airway function in asthma. Am J Med 2003;114:391-396.

48. Cockcroft DW, Swystun VA. Asthma control versus asthma severity. J Allergy Clin Immunol 1996;98(6 Pt 1):1016-1018.

49. Jatakanon A, Lim S, Barnes PJ. Changes in sputum eosinophils predict loss of asthma control. Am J Respir Crit Care Med 2000;161:64-72.

50. Ward C, Pais M, Bish R, Reid D, Feltis B, Johns D, Walters EH. Airway inflammation, basement membrane thickening and bronchial hyperresponsiveness in asthma. Thorax 2002;57:309-316.

51. Turktas H, Oguzulgen K, Kokturk N, Memis L, Erbas D. Correlation of exhaled nitric oxide levels and airway inflammation markers in stable asthmatic patients. J Asthma 2003;40:425-430.

52. Van Den Berge M, Meijer RJ, Kerstjens, HAM, de Reus DM, Koeter GH, Kauffman HF, Postma DS. PC(20) adenosine $5^{\prime}$-monophosphate is more closely associated with airway inflammation in asthma than PC(20) methacholine. Am J Respir Crit Care Med 2001;163:1546-1550.

53. Spallarossa D, Battistini E, Silvestri M, Sabatini F, Fregonese L, Brazzola G, Rossi GA. Steroid-naive adolescents with mild intermittent allergic asthma have airway hyperresponsiveness and elevated exhaled nitric oxide levels. J Asthma 2003;40:301-310.

54. Vignola AM, Chanez P, Campbell AM, Souques F, Lebel B, Enander I, Bousquet J. Airway inflammation in mild intermittent and in persistent asthma. Am J Respir Crit Care Med 1998;157:403-409.

55. van den Toorn LM, Overbeek SE, de Jongste JC, Leman K, Hoogsteden HC, Prins JB. Airway inflammation is present during clinical remission of atopic asthma. Am J Respir Crit Care Med 2001;164:2107-2113.

56. de Kluijver J, Evertse CE, Schrumpf JA, van der Veen H, Zwinderman AH, Hiemstra PS, Rabe KF, Sterk PJ. Asymptomatic worsening of airway inflammation during low-dose allergen exposure in asthma: protection by inhaled steroids. Am J Respir Crit Care Med 2002;166:294-300.

57. McFadden ER Jr, Warren EL. Observations on asthma mortality. Ann Intern Med 1997;127:142-147.

58. Wenzel SE. Schwartz LB, Langmack EL, Halliday JL, Trudeau JB, Gibbs RL, Chu HW. Evidence that severe asthma can be divided pathologically into two inflammatory subtypes with distinct physiologic and clinical characteristics. Am J Respirt Crit Care Med 1999;160:1001-1008.

59. The ENFUMOSA cross-sectional European multicentre study of the clinical phenotype of chronic severe asthma. European Network for Understanding Mechanisms of Severe Asthma. Eur Respir J 2003;22:470-477.

60. Jenkins HA, Cool C, Szefler SJ, Covar R, Brugman S, Gelfand EW, Spahn JD. Histopathology of severe childhood asthma: a case series. Chest 2003;124:32-41.

61. Sont JK, Willems LN, Bel EH, van Krieken JH, Vandenbroucke JP, Sterk PJ. Clinical control and histopathologic outcome of asthma when using airway hyperresponsiveness as an additional guide to long-term treatment. The AMPUL Study Group. Am J Respir Crit Care Med 1999;159(4 Pt 1):10431051. 
62. Green RH, Brightling CE, McKenna S, Hargadon B, Parker D, Bradding P, Wardlaw AJ, Pavord ID. Asthma exacerbations and sputum eosinophil counts: a randomized controlled trial. Lancet 2002;360:1715-1721.

63. Mannino DM, Homa DM, Akinbami LJ, Moorman JE, Gwynn C, Redd SC. Surveillance for asthma-United States, 19801999. MMWR Surveill Summ 2002;51:1-13.

64. Asthma in America, a landmark survey. Glaxo Wellcome Inc. 1998. Also available at: http://www.asthmainamerica.com/index.htm.

65. ten Brinke A, Zwinderman AH, Sterk PJ, Rabe KF, Bel EH. Factors associated with persistent airflow limitation in severe asthma. Am J Respir Crit Care Med 2001;164:744-748.

66. Vonk JM, Jongepier H, Panhuysen CI, Schouten JP, Bleecker ER, Postma DS. Risk factors associated with the presence of irreversible airflow limitation and reduced transfer coefficient in patients with asthma after 26 years of follow up. Thorax 2003;58:322-327.

67. Cerveri I, Locatelli F, Zoia MC, Corsico A, Accordini S, de Marco R. International variations in asthma treatment compliance: the results of the European Community Respiratory Health Survey (ECRHS). Eur Respir J 1999; 14:288-294.

68. White MV, Sander N. Asthma from the perspective of the patient. J Allergy Clin Immunol 1999;104(2 Pt 2):S47-52.

69. Lang DM, Sherman MS, Polansky M. Guidelines and realities of asthma management. The Philadelphia story. Arch Intern Med 1997;157:1193-1200.

70. Legorreta AP, Christian-Herman J, O'Connor RD, Hasan MM, Evans R, Leung KM. Compliance with national asthma management guidelines and specialty care: a health maintenance organization experience. Arch Intern Med 1998;158:457-464.

71. Stafford RS, Ma J, Finkelstein SN, Haver K, Cockburn I. National trends in asthma visits and asthma pharmacotherapy, 1978-2002. J Allergy Clin Immunol 2003;111:729-735.

72. Piecoro LT, Potoski M, Talbert JC, Doherty DE. Asthma prevalence, cost and adherence with expert guidelines on the utilization of health care services and costs in a state Medicaid population. Health Serv Res 2001;36:357-371.

73. Vermeire PA, Rabe KF, Soriano JB, Maier WC. Asthma control and differences in management practices across seven European countries. Respir Med 2002;96:142-149.

74. Makino S, Furusho K, Ohta K, Mukoyama T. A survey on awareness and utilization of new asthma management guidelines in Japan. J Asthma 2003;40:701-708.

75. Braganza S, Sharif I, Ozuah PO. Documenting asthma severity: do we get it right? J Asthma 2003;40:661-665.

76. Wolfenden LL, Diette GB, Krishnan JA, Skinner EA, Steinwachs DM, Wu AW. Lower physician estimate of underlying asthma severity leads to undertreatment. Arch Intern Med 2003;163:231-236.

77. Cabral AL, Carvalho WA, Chinen M, Barbiroto RM, Boueri FM, Martins MA. Are international asthma guidelines effective for low-income Brazilian children with asthma? Eur Respir J 1998;12:35-40.

78. Vollmer WM, O'Hollaren M, Ettinger KM, Stibolt T, Wilkins J, Buist AS. Linton KL, Osborne ML. Specialty differences in the management of asthma. A cross-sectional assessment of allergists' patients and generalists' patients in a large HMO. Arch Intern Med 1997;157:1201-1208.

79. Bateman ED, Bousquet J, Braunstein GL. Is overall asthma control being achieved? A hypothesis-generating study. Eur Respir J 2001;17:589-595.

80. Bateman ED, Frith LF, Braunstein GL. Achieving guideline-based asthma control: does the patient benefit? Eur Respir J 2002;20:588-595. 